\title{
Enhancing natural resource management through payment for ecosystem services
}

\author{
S. Vemuri ${ }^{1} \&$ J. Gorman ${ }^{2}$ \\ ${ }^{I}$ School of Law and Business, Faculty of Law, Business and Arts (LBA), \\ Charles Darwin University, Australia \\ ${ }^{2}$ School for Environmental Research, Institute of Advanced Studies, \\ Charles Darwin University, Australia
}

\begin{abstract}
There is evidence to suggest that for $>60,000$ years prior to European colonisation, Indigenous Australians used ecosystem services and managed landscapes sustainably. Since that time and in the wet/dry tropics of the Northern Territory, fire, weeds and feral animals have had, and continue to have, the greatest influence on landscapes and the ecosystem services they provide. Internationally, the links between Indigenous people and their experiences with natural and cultural resource management has been recognized and now have become an important and popular strategy for promoting sustainable development. Indigenous Natural and Cultural Resource Management (INCRM) is particularly relevant in the Northern Territory of Australia and has contributed to the formation of an Indigenous ranger program to manage threats to the landscape in conjunction with customary land management practice from Aboriginal people still living on their country. A closer examination of the success of INCRM suggests that the real challenge is one of managing knowledge pluralism rather than finding a common base for the different sources of knowledge. More recently these landscapes have been subject to a number of additional threats (spread of disease from feral animals, illegal international fishing vessels, exotic ant control, fire abatement etc), which still require management at a local level. Many of these are currently being managed under a payment for environmental service (PES) type arrangement. While PES has great public cost-benefit, it needs to be determined if the model provides the best mechanism for the progress of Indigenous people. This paper is about the intricacies of issues related with linking knowledge of Indigenous people with
\end{abstract}


provision of ecosystem services and will conclude the ongoing commitment of PES to sustainable development.

Keywords: PES, aboriginal, holistic, governance, aboriginal, rangers.

\section{Introduction}

This paper examines the current importance placed on Payment for Ecosystem Services (PES) as a tool for enhancement of nature's resources. In so doing, there is a need to take heed from Hicks [1] and note that "if one says that the economist is concerned with the present, that is just another way of saying he is concerned with the past and with the future." In particular the focus of the paper is on the phylogenic conception of evolution of four units of selection based on the taxonomy suggested by Hodgson [2], namely individuals, routines, institutions and systems. The paper suggests that the contemporary importance of PES in Natural Resource Management is a cumulative effect of the process of adaptation of means and ends between agents to achieve pluralistic outcomes. This is partly the reason for acceptance of PES by all participants in the NRM process. Unfortunately such an acceptance does not automatically imply enhancement of NRM.

The Northern Territory of Australia is selected as the study site for examining the enhancement of resource management through PES, as it provides an opportunity to study the integrated nature of the functions of the natural environment as suggested by de Groot [3], with the public policy initiatives such as Caring for Country and Indigenous Ranger programs adopted by the Australian Government through National Heritage Trusts and the National Action Plan for Salinity and Water Quality.

The paper is organized as follows. The first section of the paper describes the challenges facing NRM in the context of Northern Australia. The second section of the paper traces the historical context of PES in the Northern Territory of Australia. The third section of the paper examines the current status of PES related activity. In the final section the paper discusses the future importance of PES in enhancing NRM.

\section{Northern territory and NRM}

The Northern Territory of Australia is a region with unique natural and social values. There is a great diversity of plants and animals associated with habitats which range from rainforests, mangrove forests, swamps and wetlands in the wet/dry tropics in the north through to hummock grasslands and mulga shrub lands of the desert areas in the south. Culturally there is also great diversity with over 200 Aboriginal communities living in this area with intact spiritual connections and obligations to care for and manage country. Aboriginal people consider country as being 'a living entity with a yesterday, today and tomorrow, with a consciousness, and a will towards life' (Rose [4]). Without people living on the land in remote Northern Territory landscapes there are threats from fire, disease, feral animals, illegal fishing, and bio-security and left unmanaged the 
very values that make this area unique and such an asset to Australia would be seriously undermined.

Indigenous owned land in the NT includes some of the most bio-diverse lands in Australia (Altman et al. [5]; DNRETAS [6]). These include many of the most intact and nationally important wetlands, riparian zone, forests and rivers and water ways. Despite their relative intactness these lands are at risk of species contraction and face major threats from feral animals, exotic weeds, changed fire regimes, pollution and over grazing (Garnett and Woinarski [7]).

In the Northern Territory (NT) of Australia Aboriginal people are progressively seeking greater empowerment and self-determination of their lands, institutions and affairs. One way to achieve self-determination is through participating in business related activities. Concerted attempts are underway to promote enterprise development. Most economic opportunities exist for Indigenous people through managing their lands and utilizing their plant and animal resources (SRRATRC [8]). Many contributions to the field of sustainability have not only recognized but also acknowledged the significant role of traditional Indigenous knowledge to commercialization of land management activities. Discussions are normally couched along the lines of building capacity to deal with, and integrate, the scientific know-how with traditional environmental knowledge.

Over the years there have been several attempts to address the economic and environmental, challenges in a comprehensive manner. An understanding of these attempts will provide a historical context why PES is considered to enhance NRM.

\section{Historical context}

Historical events have shaped the way public policy has addressed issues related to NRM. Although there have been variations to the NRM policies there has been an underlying drive that jealously propagates "Shamrocks" in the form of ecology ,economy and society (Handy [9]) in the environment on the one hand and address the "hybrid" nature of the economy (Altman [10]) on the other hand.

The combination of producing Shamrocks in a hybrid context has created in essence a "Leitbild" (Pearson and Gorman [11]). This is most evident in the way NRM strategies have evolved over the years.

NRM public policy initiatives were based on establishing NRM regions and developed an integrated regional NRM plan which recognized the interconnections of people to land, sea, coasts, fresh water systems and the biodiversity of the regions. Ecological Sustainable Development (ESD) formed the guiding philosophy underlying integrated natural resource management (INRM) plans. INRM advocated the adoption of the precautionary principle and followed adaptive management practices.

The INRM plan formed the basis for regional investments from both the National heritage trust as well as the National Action Plan for Salinity and Water Quality. These investments have facilitated a transition from the INRM towards 
Table 1: Indigenous Ranger Groups in the Northern Territory (Source: NLC [12]).

\begin{tabular}{|c|c|}
\hline Land Management or Ranger Group & Area \\
\hline Acacia Larrakeyah & Adelaide River \\
\hline Adjumarllarl Community & Gunbalanya \\
\hline Asrikarrak Kirim & Peppimenarti \\
\hline Bek \& Mandiddi & W. Arnhem Land \\
\hline Belyuen & Cox Peninsula \\
\hline Demed & Gunbalanya \\
\hline Dhimurru & Nhulunbuy \\
\hline Djelk & Maningrida \\
\hline Gamarrawa Nuwul Landcare & Nhulunbuy \\
\hline Garawa & Borroloola \\
\hline Garngi & Croker Island \\
\hline Gumurr Marthakal Sea & Elcho Island \\
\hline Gurrwurrling & Ramingining \\
\hline Larrakia & Darwin \\
\hline Lianthawirriyarra Sea & Gulf Carpentaria \\
\hline Mardbalk Marine & Goulburn Island \\
\hline Malak Malak & Daly River \\
\hline Manwurrk & West Arnhem Land \\
\hline Mimal & Bulman \\
\hline Minyerri & Roper River \\
\hline Mulayee Women & VRD \\
\hline Ngaliwurru Wuli & Timber Creek \\
\hline Ngatpuk & Finnis River \\
\hline Numbulwar Numburindi Amalahgayag Inyung & Blue Mud Bay \\
\hline SE Arafura Catchment & Central Arnhem Land \\
\hline Thamarrurr Sea and Land & Wadeye \\
\hline Waanyi Garawa & Boroloola area \\
\hline Wagiman Guwardagun & Upper Daly River \\
\hline Wanga Djakamirr & Ramingining \\
\hline White Eagle & Finniss River \\
\hline Yantjarrwu & Daly/ Pt Keats \\
\hline Yugul Mangi & Ngukurr \\
\hline
\end{tabular}

integrated natural cultural resource management (INCRM). The conceptual template for NRM activities incorporated integration of the cultural elements that are deeply rooted in the psyche of the participants through the very process of acts performed by both the scientific community and the Aboriginal populations. The result of such actions can be seen when one recognizes that management of Aboriginal lands in the NT is currently through the Indigenous Ranger Groups.

Since Traditional Owners set up the Caring for Country program within the Northern Land Council in 1996, 35 Rangers Groups have been established which has employed over 400 Aboriginal people (Northern Land Council [12]). In many instances the Ranger Groups are given direction through an Aboriginal 
Resource Centre which has a management committee made up of Traditional Owners from each clan in the management area. Since their initiation, Indigenous Ranger Programs have been considered as part of the Community Development Employment Program (CDEP) which is a 'work for the dole' type welfare program which has been in existence for 30 years in the NT and has both advocates (Altman [13, 14]); and critics (Pearson [15]). As such the Ranger Programs have been regarded as a CDEP activity which has been managed through a variety of different agencies. Funding for these Ranger Groups have come from variety of different funding bodies (National Heritage Trust, National Landcare Program, Indigenous Landcare Corporation etc.) and have often been dependent on the capacity of the Rangers or their coordinators to successfully bid for and win funding. Some groups have thrived under these arrangements and now have dozens of Rangers and projects while others have not had as much success and consist of only a handful of Rangers which provide few INCRM activities. Table 1 provides a list of INCRM activities in various areas of the NT.

\section{Current status}

In recent years PES has been a progressively larger source of funding for ranger activities as the main wages component has shifted from CDEP money. A major reason for such a significant adaptation of PES in NT is the attempt by both Commonwealth and the NT governments to increase market based activities.

Following Government Intervention in Aboriginal communities announced in July 2007, CDEP was planned to be abolished and changed over to a 'work for the dole' program. Although this full time employment in this program offered slightly more money ( $\$ 20.80$ per fortnight) there would be no opportunity for 'top-up', which is extra income for more than the 4 hours CDEP work per day (Australian Government [16]). With a change of Commonwealth Government in 2008 the plan to abolish CDEP was reviewed and it was recommended that CDEP be restructured. As of 1 July 2009 the 'continuing participants', or those already involved in a CDEP program, would keep receiving CDEP wages as long as they remained eligible. Those new participants who start in a CDEP program would receive income support from Centrelink which would be income managed. Centrelink is the Australian government authority responsible for providing access to government services, including social security allowances and employment plans. Furthermore, between 1 July 2011 and 30 September 2011 all of the 'continuing participants' would be moved off CDEP and onto income support (Australian Commonwealth Government [17]).

While these changes to CDEP were happening the Commonwealth Government put forward a Working on Country initiative was to fund the Indigenous Ranger Program. This was initially \$20 million dollars over 5 years but was then expanded to $\$ 90$ million over 5 years from 1 July 2008. This program now provides a wage to rangers which had superannuation, leave and sickness benefits that CDEP did not. It appears that formal INCRM is now following a much more reasonable employment path and these important 
activities area being recognized as a real job. There are however many Aboriginal people that are not receiving any benefit for the management services they are providing and it is this group who will struggle to remain on country with changes to CDEP.

In May 2009 the Northern Territory Government announced a new strategy and vision for Indigenous communities titled a Working Future. This strategy involved six elements which include: establishment of 20 towns across the Territory, a clear path for Outstations and Homelands, delivery of remote services in a targeted and coordinated way with the Australian Government, employment and economic development, a remote transport strategy and closing the Gap targets and evaluation (Northern Territory Government [18]).

The consequences of the Working Future strategy coupled with changes to CDEP are likely to contribute to urban drift of Aboriginal people from remote outstations and townships. A further depopulation of these remote areas will have long term biophysical and cultural impacts because it will disconnect people from country leaving less people involved in natural and cultural resource management. Indigenous Ranger Groups and the Indigenous Resource Centres that support Traditional Owners are looking for ways to generate an income from their country whilst also maintaining traditional knowledge.

\section{Enhancing the future of NRM through PES}

Attempts to enhance NRM by integrating the scientific and Indigenous knowledge systems have resulted in explicit recognition of the significant role played by the INCRM practices.

INCRM can be considered a major economic development opportunity for Aboriginal people seeing as they have knowledge, skills and capacity in this area. Given this opportunity, searches are underway to expand the INCRM practices to enable greater participation amongst Aboriginal people. Attempts are being made in earnest to drive the market based agenda based on INCRM. There are a number of PES activities that are already starting to provide an alternative avenue of funding which can support a presence on country. It is also necessary to recognize that some form of payment is rendered for the services provided by the Indigenous rangers. Table 2 summaries the characteristics of these PES activities in a form that is comparable with similar PES programs in other countries (adapted from Wunder [19]).

Existing PES schemes in the Northern Territory are still relatively new, but recent government initiatives have acknowledged the role of Indigenous Ranger Groups for services provided in relation to biodiversity protection, border protection, ongoing cultural maintenance, employment initiatives in remote communities and biosecurity (Muller [20]; Luckert et al. [21]). Many conservation and development organisations look at PES as a just way of rewarding poor rural people for looking after their environment which continuously provides environmental service (Shilling and Osha [22]; Rosa et al. [23]; van Noordwijk et al. [24]). However, others consider it from an efficiency point of view only as those that constitute a credible threat to ecosystem service 
Table 2: Summary characteristics of PES programs carried out by Indigenous rangers groups.

\begin{tabular}{|c|c|c|c|}
\hline $\begin{array}{c}\text { Environmental } \\
\text { service }\end{array}$ & Who buys & Who sells & Area \\
\hline $\begin{array}{c}\text { Disease monitoring } \\
\text {-ants, mosquito, } \\
\text { pigs, buffalo } \\
\text { monitoring } \\
\end{array}$ & $\begin{array}{l}\text { Australian } \\
\text { quarantine } \\
\text { Inspection } \\
\text { Service, } \\
\text { Department of } \\
\text { Agriculture, } \\
\text { Fisheries and } \\
\text { forestry } \\
\end{array}$ & $\begin{array}{c}\text { Adjumarllarl } \\
\text { Community Rangers, } \\
\text { Djelk Rangers, Larrakia } \\
\text { Rangers, Mardbalk } \\
\text { Rangers, Malak Malak } \\
\text { people, Manwurrk } \\
\text { Rangers, Ngaliwurru } \\
\text { Wuli Land } \\
\text { management, Yirralka } \\
\text { Rangers, Yugal Mangi }\end{array}$ & $\begin{array}{c}\text { Gunbalanya, Maningrida, } \\
\text { Darwin, Goulbourn } \\
\text { Island, Woolianna, } \\
\text { Kabulwarnamyo, Timber } \\
\text { Creek, N.E. Arnhem } \\
\text { Land, Ngukurr }\end{array}$ \\
\hline $\begin{array}{c}\text { Patrols for illegal, } \\
\text { unreported and } \\
\text { unregulated fishing }\end{array}$ & NT Fisheries & $\begin{array}{c}\text { Mardbalk Rangers, } \\
\text { Gumurr Marthakal Sea } \\
\text { Rangers, Djelk Rangers, } \\
\text { Lianthawirryarra } \\
\text { Rangers, Thamarrurr } \\
\text { Rangers, Tiwi Rangers, } \\
\text { Anindilyakwa rangers, } \\
\text { Yugal Mangi Landcare }\end{array}$ & $\begin{array}{l}\text { Goulbourn Island, Elcho } \\
\text { Island, Maningrida, } \\
\text { Borroloola, Wadeye, } \\
\text { Melville and Bathurst, } \\
\text { Groote Island, Ngukurr }\end{array}$ \\
\hline $\begin{array}{l}\text { Illegal Fishing } \\
\text { vessels }\end{array}$ & $\begin{array}{l}\text { Australian } \\
\text { Customs and } \\
\text { immigration } \\
\end{array}$ & Djelk Rangers & Arnhem Land Coastline \\
\hline $\begin{array}{c}\text { Ghost net } \\
\text { surveillance } \\
\text { management }\end{array}$ & $\begin{array}{l}\text { Carpentaria } \\
\text { Ghost Nets } \\
\text { Programme } \\
\end{array}$ & $\begin{array}{l}\text { Dhimirru, Gumurr } \\
\text { Marthakal Sea Rangers, } \\
\text { Numbulwar Rangers, } \\
\text { Yirralka, Yugal Mangi }\end{array}$ & $\begin{array}{l}\text { N.E. Arnhem Land, } \\
\text { Elcho Island, Roper } \\
\text { River, Blue Mud Bay, } \\
\text { Ngukurr }\end{array}$ \\
\hline $\begin{array}{l}\text { Monitoring and } \\
\text { eradication of } \\
\text { yellow crazy ant } \\
\text { infestations } \\
\end{array}$ & CSIRO & Dhimurru Rangers & East Arnhem Land \\
\hline $\begin{array}{c}\text { Landscaping and } \\
\text { revegetation }\end{array}$ & $\begin{array}{c}\text { Alcan } \\
\text { Refinery, } \\
\text { Nhulunbuy }\end{array}$ & $\begin{array}{c}\text { Gamarrawa Nuwul } \\
\text { Landcare }\end{array}$ & Nhulunbuy \\
\hline Fire abatement & $\begin{array}{c}\text { ConocoPhillips } \\
\text { and NT } \\
\text { Government }\end{array}$ & $\begin{array}{c}\text { Jawoyn Rangers, Djelk } \\
\text { Rangers, Demed } \\
\text { Rangers, Manwurrk } \\
\text { Rangers, Mimal } \\
\text { Rangers } \\
\end{array}$ & Maningrida - Katherine \\
\hline Fire management & $\begin{array}{l}\text { Neighbouring } \\
\text { pastoral } \\
\text { properties }\end{array}$ & Minyerri Rangers & Roper River \\
\hline
\end{tabular}


(ES) provision should be paid (Wunder [19]). This being the case, should only areas under immediate threat be open to PES activities? In practice there are no easy answers and PES schemes need to strike a balance between short-run efficiencies and long term viability (Wunder [19]). In the Northern Territory most Aboriginal land is under communal title and as such has restricted commercial development opportunity. Private investment is limited and land is generally agriculturally marginal but relatively intact providing functional ecosystem services. Government initiatives to boost the economy on Aboriginal land through encouraging private investment (by providing greater long term security through allowing for 99 year leases and abolishment of the permit system) along with greater activity from the mining industry from a recent resources boom are contributing to an increase in threats to ecosystem services on this country.

Indigenous people are well equipped to provide valuable input into the management of resources and associated ES under a PES type agreement due to their considerable existing knowledge and skills base, demonstrated commitment and location. However, most of the activities that Indigenous rangers provide cannot be strictly classified as PES activities as defined by Wunder [19] as although their ICNRM activities may maintain a variety of ES their payment may not necessarily be based on performance. There are other funding models such as the now defunct Top End Aboriginal Land Management and Employment Strategy which was funded largely to control the spread of an exotic plant Mimosa pigra (Ashley et al. [25]) which could be considered similar to a PES activity as performance was an important criteria for continuation of funding. There are however a number of activities that are currently operating through Indigenous Ranger Groups in the Northern Territory that can be classified as PES activities (Table 3). The majority of these schemes are

Table 3: Summary of the Indigenous land and Sea Rangers manager activities that can be classed as PES activities.

\begin{tabular}{|c|c|c|c|c|c|c|c|c|c|c|c|c|c|}
\hline $\begin{array}{l}\text { Ranger } \\
\text { Activity }\end{array}$ & 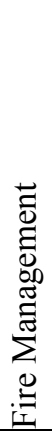 & 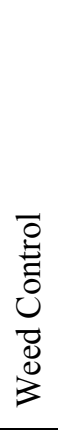 & 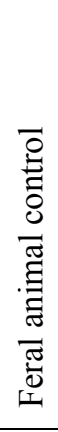 & 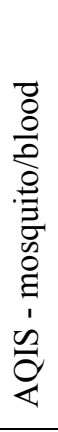 & 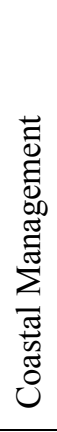 & 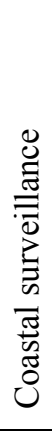 & 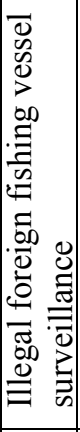 & 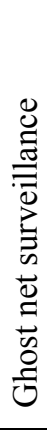 & 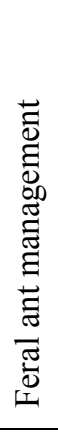 & 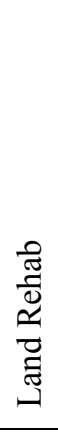 & 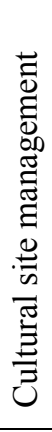 & 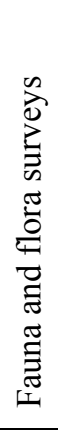 & 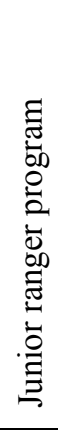 \\
\hline $\begin{array}{c}\text { PES } \\
\text { Activity }\end{array}$ & $\sqrt{ }$ & $\sqrt{ }$ & $\sqrt{ }$ & $\sqrt{ }$ & $\sqrt{ }$ & $\sqrt{ }$ & $\sqrt{ }$ & $\sqrt{ }$ & $\sqrt{ }$ & $\sqrt{ }$ & $\sqrt{ }$ & $\sqrt{ }$ & $\sqrt{ }$ \\
\hline
\end{tabular}


government financed programs but there are also a few user-financed programs involved. These activities are voluntary with the ES generally being well defined but, as found by Wunder [26] it appears that in most cases payments are nominally conditional within the government-financed programs than in userfinanced programs (such as WALFA, exotic ant control).

Some have suggested that the Australian Government could be considered to be 'free-riding' on the provision of these INCRM services by Aboriginal people (Luckert and Whitehead [27]). These management practices deliver outputs which are of public good/benefit (reduced carbon, disease control, coastal surveillance, feral animal and weed control etc) at several levels (local, national and international) (Muller [20]; Luckert et al. [21]). As such, all of the people that provide their services should be recompensed for their activity. Notwithstanding this, the basic premise has been to provide a meaningful way for Aboriginal people to be gainfully engaged in promoting management of the five capitals - economic, environment, social, cultural and human, in a sustainable manner.

The future of PES in enhancing NRM will largely depend upon the extent of involvement of Indigenous people to the market based agenda. Records based on past experiences with employment, education and enterprise development initiatives that are predominately market oriented are not very encouraging. A major reason for such a poor track record of market engagement by Aboriginal populations is the adoption of a 'deficit' approach to private sector involvement.

PES has all the essential in-built features to become an imaginative tool for enhancing NRM practices. To achieve its full potential there is a need to take heed of lessons from current and past experiences.

There are a number of PES activities happening in the Northern Territory that are providing employment and income generating opportunities for Indigenous Ranger Groups that have the capacity and skills for these activities. Many of these activities operate through Ranger Groups because transaction costs are lower and these groups have a certain amount of operational capacity. However, there are many Indigenous people living on Aboriginal land in remote parts of the Northern Territory who are not affiliated with a Ranger Group, who also have NCRM skills and obligations, who are reliant on CDEP and would welcome the opportunity to participate in PES activities. It is important to develop a framework which allows participation from a larger pool of people across the NT than just those affiliated with Ranger Groups.

Experiences from other similar environments such as Canada suggest the significance of broader involvement.

"Broader involvement at the community level was restricted because specific local actors coalesced to skew participation toward a narrow set of economic values. Selected participants in the co-management exercise maintained close control over participation within the community and effectively became a conduit to senior government for vocal sectors at the local level. The locally 
dependent status of committee members resulted in proposals for modest change, without an overall vision or commitment to implementation."

A starting point in embracing such a lateral approach is to recognise that provision of environmental services is neither about science nor service provision alone but about context, culture (Muller [20]) connection, continuity, change, competition, and cooperation. Thus, there is potential to make the process that of 'a-colonisation' where Indigenous and non-Indigenous governance systems connect and work together rather than a top down or prescribed 'colonised' approach. In addition to creating a more correct process of engagement, recognition and remuneration for environmental services, it is essential to conceptualise how INCRM services can be assigned appropriate values, promote livelihood benefits, and that can be distributed to all the people involved in providing these services. In short, it is not simply generating processes of production by Aboriginals themselves for themselves and the rest of the Australian society but it involves adoption and promotion of a 'holistic' perspective that includes production, distribution and consumption values of environmental services.

PES should therefore not be restricted to becoming simply a tool for calculating monetary values of payment for services rendered (resulting from market failure) but it should be able to incorporate how services that are produced, consumed and distributed in a community setting can be valued. As a result PES becomes an organizational framework that can be used effectively to manage the environment by espousing sustainable management principles. There are several initiatives that are built on market based instrumentations related to price; quantity and market features should be incorporated when discussing PES. The PES framework then can generate initiatives that are based on a premise to find alternatives to publicly funded operations. However this has not happened to a large extent in the case of Northern Australia.

\section{References}

[1] Hicks, J. A theory of economic history, Claredon Press, p.3, 1969.

[2] Hodgson, G.M., The economics of Institutions, International library of critical writings in economics, 33, Elgar Reference Collection, 1993.

[3] de Groot, R. Functions of Nature: Evaluation of Nature in Environmental Planning, Management and Decision Making, Wolters-Noordhoff, Groningen, the Netherlands, 1993.

[4] Rose, D.B., Nourishing terrains: Australian Aboriginal views of landscape and wilderness, Australian Heritage Commission, Canberra, 1996.

[5] Altman, J.C., Kerins, S., Fogarty, B. \& Webb, K., Why the Northern Territory government needs to support outstations/homelands in the Aboriginal Northern territory and national interests, Centre Aboriginal Economic Policy Research Tropical Issue No. 17/2008, Centre for 
Aboriginal Economic Policy Research, Australian National University, Canberra, 2008.

[6] Department of Natural Resources the Arts and Sport, Northern Territory Parks and Conservation Masterplan, Northern Territory Government, Darwin, 2005.

[7] Garnett, S.T. \& Woinarski, J.C.Z., A case for Indigenous threatened species management (Chapter 5). Investing in Indigenous Natural Resource Management, ed. M.K. Luckert, B.M. Campbell, J.T. Gorman and S.T. Garnett, pp. 38-44, Charles Darwin University Press, Darwin, 2007.

[8] SRRATRC. Commercial utilisation of Australian native wildlife, Report of the Senate Rural and Regional Affairs and Transport References Committee, Parliament of the Commonwealth of Australia, Canberra, 1998.

[9] Handy, C., The Elephant and the Flea, Random House, Arrow, NSW, 2002.

[10] Altman, J.C., Sustainable development options on Aboriginal land: The hybrid economy in the twenty-first century, Centre Aboriginal Economic Policy Research Discussion Paper 226, Australian National University, Canberra, 2001.

[11] Pearson, D.M. \& Gorman, J.T. Managing landscapes of the Australian Northern Territory for sustainability: Visions, issues and strategies for successful planning, Futures, 2009 (in press).

[12] Northern Land Council, Celebrating Ten Years of Caring for Country, a Northern Land Council Initiative, Northern Land Council, Darwin, 2006.

[13] Altman, J.C. In Search of an Outstations Policy for Indigenous Australians, Centre Aboriginal Economic Policy Research, Australian National University, Canberra, 2006.

[14] Altman, J.C. Scrapping CDEP is just plain dumb. Crickey Magazine, 2007.

[15] Pearson, N. Stuck on the Welfare Pedestal. The Weekend Australian: Inquirer, p. 28, Perth, 2007.

[16] Australian Government, Community Development Employment Projects (CDEP) Program. Program Guidelines 2009-12, Department of Families, Housing, Community Services and Indigenous Affairs, Canberra, 2007.

[17] Commonwealth Government of Australia, Increasing Indigenous economic opportunity. A discussion paper on the future of the CDEP and indigenous employment programs Department of Education, Employment and Workplace Relations, Canberra, 2009.

[18] Northern Territory Government. Working Future. http://www.working future.nt.gov.au/. Canberra, 2009.

[19] Wunder, S., Payments for Environmental Services: some nuts and bolts, Occasional Paper No. 42, Centre for International Forestry Research, Bogor, 2005.

[20] Muller, S. Indigenous Payment for Environmental Service (PES) Opportunities in the Northern Territory: negotiating with customs, Australian Geographer 39, pp. 149-170, 2008. 
[21] Luckert, M.K., Campbell, B.M., Gorman, J.T. \& Garnett, S.T. (eds.). Investing in Indigenous Natural Resource Management, Charles Darwin University Press, Darwin, 2007.

[22] Shilling, J. \& Osha, J., Paying for environmental stewardship: using markets and common-pool property to reduce rural poverty while enhancing conservation, World Wildlife Fund, Washington D.C., 2003.

[23] Rosa, H., Kandel, S. \& Dimas, L., Compensation for environmental services and rural communities, Programa Salvadoreño de Investigación sobre Desarrollo y Medio Ambiente (PRISMA), San Salvador, El Salvador, 2003.

[24] van Noordwijk, M., Chandler, F. \& Tomich, T.P., An introduction to the conceptual basis of RUPES: rewarding upland poor for environmental services, World Agroforestry Center, Bogor, 2004.

[25] Ashley, M., Storrs, M.J. \& Brown, M., Caring for Country: Community based mimosa management on Aboriginal lands of the Top End of the Northern Territory. Proceedings of the 3rd International Mimosa Symposium, pp. 106-109, CSIRO, Darwin. (2002)

[26] Wunder, S. Necessary conditions for ecosystem service payments Proceeding from Economics and Conservation in the Tropics: A Strategic Dialogue, San Francisco, 2008.

[27] Luckert, M.K. \& Whitehead, P.J. A general case for natural resources management: market failures and government policy (Chapter 2). Investing in Indigenous natural resource management, ed. M.K. Luckert, B.M. Campbell, J.T. Gorman and S.T. Garnett, Eds.), pp. 11-18, Charles Darwin University Press, Darwin. 2007. 